\title{
Life Around the Firewood Stove: The Impact of Price Volatility
}

\section{Alma Lucrecia Olivet López}

\begin{abstract}
The cooking fire at home is an important site for the transmission, through the oral tradition, of the continuity of history and culture. In Guatemala, cooking and eating around the fire is one of the ancestral practices that promotes communication between family members. The heat provided by firewood is exploited to cook and maintain a comfortable temperature inside the house, but also to transmit teachings and ancient secrets. The fire provides energy at the centre of family cohesion before and after the work day. Today, although families still gather around the stove, the practice is diminishing, in part because of the rising cost of food and firewood. This article looks at the way in which rising prices affect the use of firewood and considers the impact that this has on the transmission of cultural values from one generation to the next.
\end{abstract}

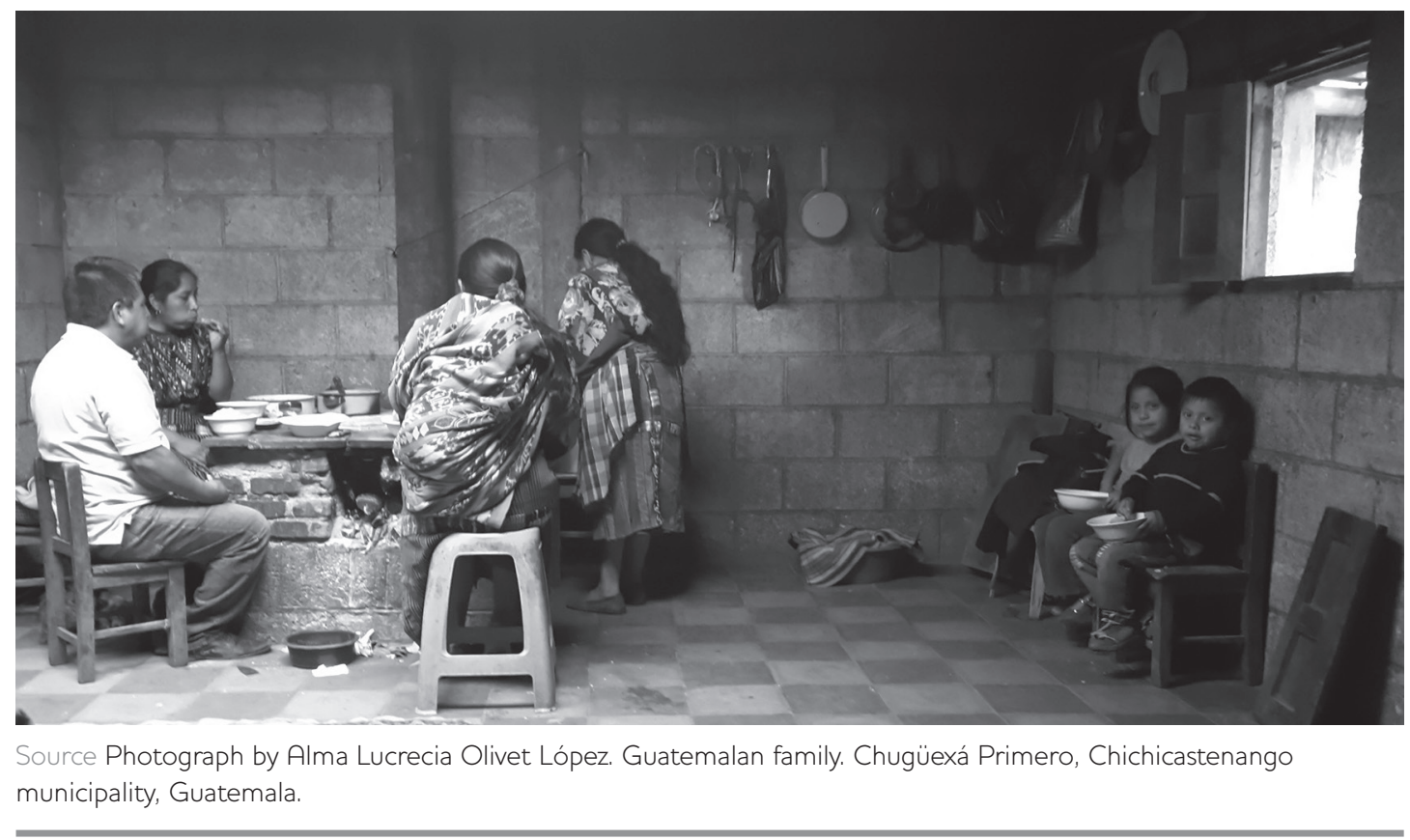

\section{Introduction}

The smell of coffee in its last boil is the alarm that gets children out of bed; it is the indicator that the time to start the day has come. The coffee is ready and the food is on the table, although the classic menu for those who attend school or go to work from the average urban household is just coffee with bread. When time allows, the family sits down and eats together. In the rural communities, it is freshly cooked corn porridge and the smell of tamalitos ${ }^{1}$ that fills the house in the morning and usually the family shares breakfast around the cooking stove and the fire. The food itself is a blending of tastes, smells and colours that culminate in the act of eating and the transmission of culture. For generations, the habit of meeting around the fire has created a space for parenting practices in Guatemala. 
Food is about more than eating. It involves a whole process from the time of production, acquisition, preparation and cooking to the time of consumption. It involves customs and rituals that characterise country, community and family. In a multicultural country like Guatemala, the cultural elements that revolve around these dynamics are as diverse as its people, their languages, practices and beliefs. These languages and the values they embody move from father and mother to daughter and son in the heat of the firewood stoves. But today the time to sit down to eat together is losing its value and its place as a cultural practice in which attitudes, feelings, postures, gestures, rituals and customs converge (Rossi n.d.).

Price in relation to income and time have become central factors behind the changes or extinction of cultural patterns. In recent years food prices have been rising in Guatemala and with them the price of firewood. Dependence on food and fuel purchase has arisen in part because conditions of land ownership have greatly deteriorated for many Guatemalan farming families. Many families now have no land at all, or have only the piece of land on which their house stands (Observatorio del Gasto Social 2008). As a result, subsistence production has diminished and family members are migrating to other areas in search of employment, including many to urban areas (Zavala 2014). The combination of commoditisation and rising prices has had major implications for family life.

Studies that investigate the change or extinction of cultural patterns that revolve around food argue that this is due mostly to the families' incomes that are affected; and this impacts on the access to adequate food. To this point is also added that 'it is a reality that the Guatemalan school, instead of strengthening the identity of vulnerable groups, isolates them and culturally uproots them’ (Núñez 1998).

\section{Method}

This article is based on a three-year longitudinal study in two largely indigenous communities in western Guatemala, one urban, the municipality of Chichicastenango and one rural, the community of Chugüexá Primero. The methodology involved annual visits to specific households within these communities to hold in-depth interviews with individuals and key informants along with focus group discussions. Using a sociological approach, the team of Guatemalan researchers attempted to understand the effect of food and fuel price volatility not only on individuals and their households, but also on generally accepted standards and practices.
The study aims to contribute towards relevant policies to better manage the impacts of rising prices of essentials. The writing of this article also involved a review of government policies and programmes and an analysis of secondary data around the use of firewood in food preparation and family life.

\section{Characteristics of use and consumption of firewood in Guatemala}

The relative availability of firewood is the origin of the traditional flavours of Guatemalan cooking. The National Forestry Institute (INAB) determined that 65.8 per cent of Guatemalans have firewood as a main source of energy (INAB et al. 2012). Firewood represents 63 per cent of national energy consumption, of which 98 per cent is for domestic purposes and 2 per cent is for industrial use (ibid). Today, wood as fuel is used mainly in rural households, though even in urban areas, some 82 per cent of households use firewood to cook maize and beans (de León 2009). The tradition is that food is cooked in clay pots on a 'three stones' open fire. Of households that cook with firewood, 81 per cent of them use three stones or their variations while the remaining 19 per cent use improved stoves (ibid).

According to data collected from household informants in the urban area of Chichicastenango, three out of ten households ( 30 per cent) combine the use of firewood and propane stoves; five out of ten only use propane stoves and the other two use only firewood. This means that 50 per cent of families are still using firewood and 80 per cent are using propane stoves (with 30 per cent at the intersection using both). In rural Chugüexá Primero, one out of ten households combine the two energy sources while the other nine households use only firewood. As urbanisation increases there has been a decline in the percentage of households using firewood. Whereas 85 per cent of the population reported firewood as their energy source in 1964, the percentage fell to 78.6 per cent in 1999 and 65.8 per cent in 2011 (de León 2009).

\section{Rising prices of staple foods also affects the use of firewood}

Despite the fact that it is impossible for most households to prepare food without it, the official measure of the basic food basket in Guatemala does not include firewood. The cost of the basket is already higher than the minimum wage, even before including the cost of firewood: in May 2015, the minimum wage was GTQ2,644.40 (US\$343) and the cost of the basic basket was GTQ3,358.50 (US\$435) (INE 2015b). According to data collected 


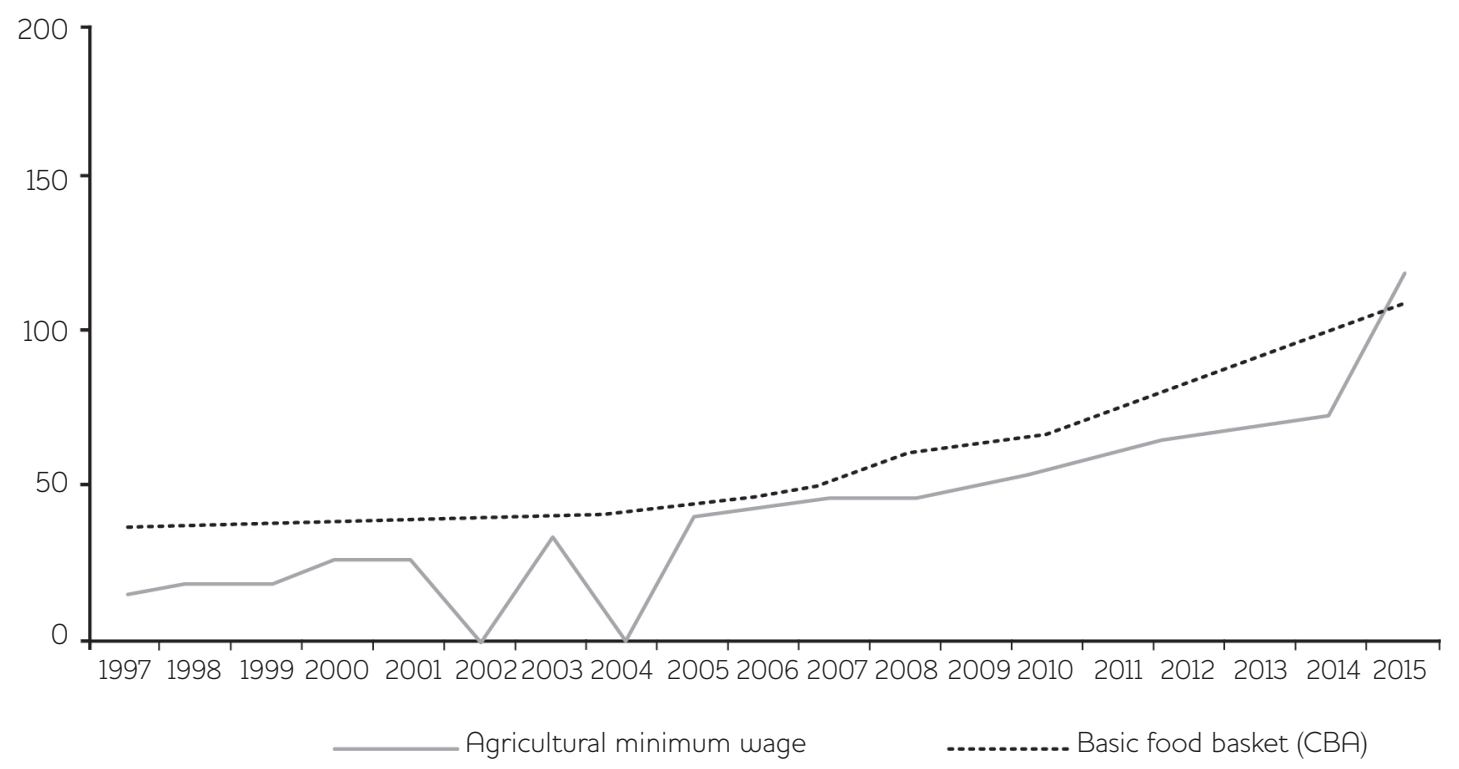

Source Author's elaboration based on data from the National Statistics Institute (INE) and Central America Journal (INE 2015a).

in household interviews, ${ }^{2}$ the average price of a tarea of firewood $^{3}$ in 2014 was between GTQ250.00 and GTQ300.00 (US\$32 and US\$39). A five-person household consumes around 1 tarea per month.

The Guatemalan economy operates on the principle of a free market and thus price volatility originates in both domestic and international production and trade. Population and demand is growing and local supply is diminishing because small-scale agricultural production is decreasing (REDSAG 2012). With lower supply and higher demand, prices have risen considerably. When international and local prices spiked in 2007/08 and again in 2011 many low-income householders opted to change traditional foods they once ate regularly for cheaper processed products. As prices continued to rise, people in urban areas also looked for alternative mechanisms to stretch the family budget and began to use propane stoves as a cheaper option. In recent years this change has also begun to emerge in the rural study community. The propane stove manufacturing industry has diversified so that even people with limited resources can find suitable models available on the market.

\section{Changing ways of cooking}

In the study sites it has been possible to identify a marked difference in how the rising price of firewood has affected relationships in the households.
This has been evidenced by concerns raised by a wide range of people including leaders, teachers, formal and informal local authorities, young people and women about threats to the practice of cooking, eating and talking together around the fire. Rising costs and new stresses on limited incomes mean that many households cannot afford to use firewood and choose to use propane instead. Ms G., a 21 -yearold participant ${ }^{4}$ in a focus group discussion in Chichicastenango explained:

A load of firewood has an average cost of Q40.00 (US\$5.18) and is not even enough for a week, while a 25 pounds cylinder of propane has an average cost of Q140.005 (US\$18.13) and for an average Guatemalan family this lasts for approximately a month.

In the opinion of neighbours and informants the scarcity and rising cost of firewood is due to population growth and because people no longer have much land (smallholding) and there are fewer trees (deforestation and urban growth). 'And now it depends on how everyone takes care of their own land', indicates a community leader in 2014. 'If there is no more forest, if there are no more trees, then we have to buy the firewood and it is expensive.' Ms M., a 21-year-old community leader and housewife in Chugüexá Primero argued in 2014 that prices have risen as supplies have reduced: 'to buy a firewood 'tarea' is now more expensive... it is 


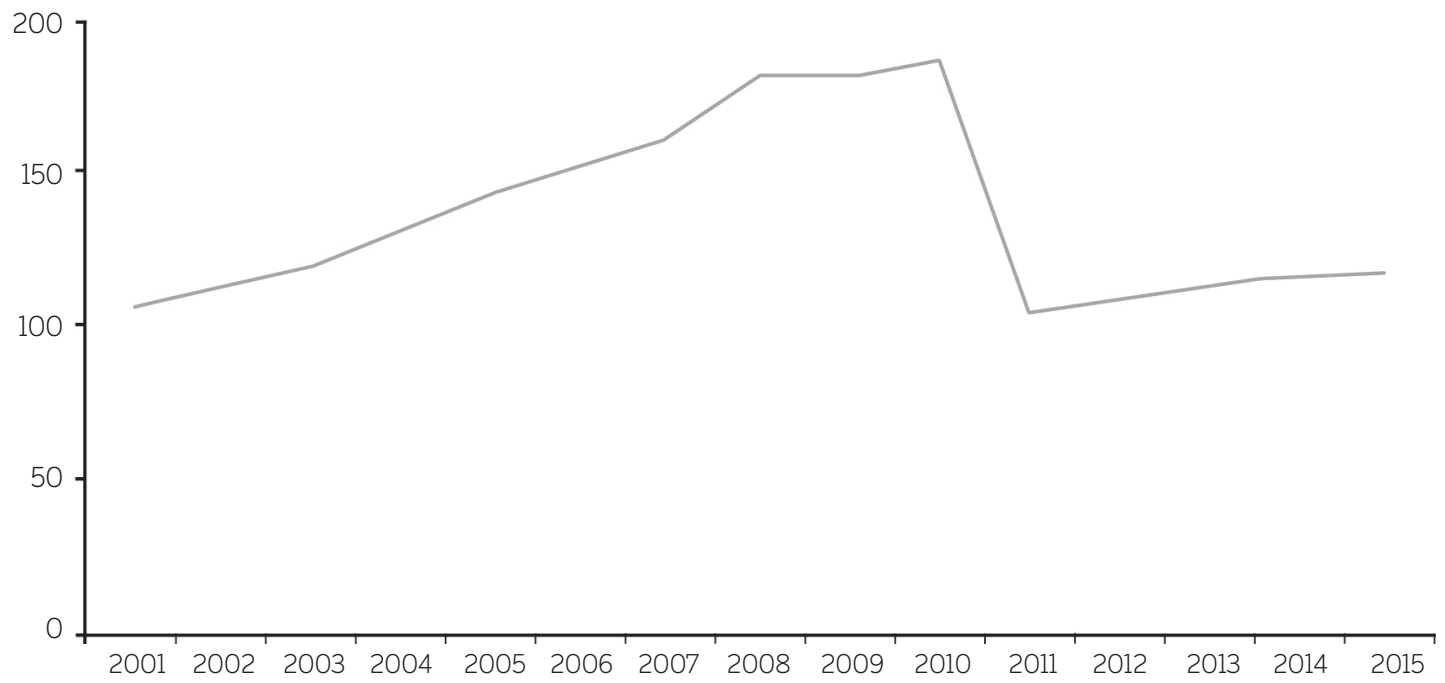

Source Author's elaboration based on data from the National Statistics Institute (INE) and Central America Journal (INE 2015b).

because of nature, since there are no longer many trees left and that is the reason why people raise the price of firewood. And this is a big expense for me because it is what my family consumes the most.'

The change to propane stoves instead of the traditional firewood stove is most frequent in the urban site, as more and more young families make the switch. In the process of change, they combine the use of both, but gradually the space used for the fire is becoming obsolete. According to informants, the use of propane is already more widespread in the urban area, of which 50 per cent have indicated they use gas exclusively and the rest combine gas and firewood. In Chugüexá Primero most households still use firewood stoves and those using gas stoves do not use them to prepare all their food; rather, they use them only in emergencies. This can be partly attributed to the fact that in rural areas the weather is colder and people tend to prefer to have the heat of the burning fire while eating (Ramírez 2009). However, a male teacher from Chugüexá Primero says that he has heard a relative say: 'I had better start using gas because I will spend less'. Another rural respondent, ${ }^{6} \mathrm{Mr} \mathrm{R}$., a 34-year-old community leader and teacher, refers to a friend in his community who began using gas and argues that 'before he spent more on firewood, and now he spends less per month using gas. The difference apparently was GTQ100.00 (US\$12.95). ${ }^{7}$ He mentions that 'people prefer to cook with gas and eat sooner so they can go to bed earlier and not suffer with the cold weather and that way they can have a little more money to cover their children's school expenses'. These changes in the way people consume energy and cook their food has considerable impacts on people's food habits, but also on other wider cultural patterns.

\section{Changing culture}

Ms C., 21 years old, community promoter, in Chugüexá Primero, explained in 2014, 'in the urban area people use the dining table, but in the rural area is almost never like that, but to gather around the cooking fire to spend time together'. As this custom is being lost, she said, 'it is as if the family is disintegrating'. A community leader ${ }^{8}$ in the village added that families there believe that, from a cultural point of view, if the fire is not used with wood, living together would not be the same: 'If we all sit around the stove, it is because of the heat'. This young lady indicated that in the family, parents, brothers, nephews, and grandparents all accommodate 'as it is possible' and they end up 'like sardines', all together. 'If someone has to say something, everyone is attentive and listen to what the other is saying... It is because of the heat from the fire and it is part of their culture. ... Firewood is important.'

There are urban families, especially young people, who no longer prepare a lot of food at home because they tend to buy everything ready to eat. They no longer cook their own beans for the entire 
week any more, but instead, when they feel like beans they buy them, whether natural or processed. The tortillas and the little corn tamales that used to be prepared at home are also now bought outside the house. They only have to be reheated on the gas stove. In this regard, informants conclude that buying food prepared outside the home is better value: 'because if we buy it outside we would get it already cooked; instead, to come home to cook it generates an expense on gas or firewood and all the ingredients plus the time it takes for its preparation. Sometimes it is not well prepared but trying to save a little we buy it like that. ${ }^{99}$

Although rural communities have been more resistant to the cultural changes caused by external influences; globalisation affects them too. It makes it cheaper to buy Chinese-made instant soup (which only needs hot water and can feed the whole family) than to buy local vegetables to prepare a homemade soup. These processed foods are preferred because they are cheaper and because they do not need further preparation and consumption of firewood. Our informants have made it clear that when the prices rise, the important thing is to seek 'to spend less so that money is enough', without considering the consequences on health and especially without considering the cultural changes that this may cause. When asking households what is most important, they reply that it is being able to have the minimum that allows them to cover the hunger: 'the most important thing is, and always the grandparents have said it: the corn, firewood, salt, chili and lime (to prepare the corn flour to make the tamalitos and the tortillas).'

Further, a custom of cultural value and that also runs on firewood, is the use of the bathhouse called temazscal (sweat lodge)..$^{10}$ Its use in urban areas is disappearing faster than in the rural areas and producing changes in practices that unite the family. The decline is attributed to the cost of firewood. Even in the rural site informants mentioned that use of the temazscal has diminished because of the increase in the price of wood fuel. A young community leader ${ }^{11}$ in the Chugüexá Primero says: 'before, not so many people went to hospital; people used natural remedies like apazote ${ }^{12}$ or went for a good steam bath in the temazscal'.

These changes have impact everywhere, but especially in indigenous communities. When asked what these changes mean, people mentioned, for instance, the implications on the knowledge and practice of the mother tongue. In Guatemala, the
Mayan language identifies the indigenous population as linguistic and cultural communities. In Guatemala there are 24 language communities (including Spanish). Twenty-one correspond to indigenous groups, including that of the Xinca community and the Garifuna community (DIGEBI 2009).

In family life the native language is transmitted and practised around the fire and while sharing food. Members of the family listen and participate in discussions in their mother tongue. Currently, there are growing numbers of young people who do not speak their native language and practice around the family circle has been lost. On the issue of values, around the fire and food, elderly people tell stories and give advice. It is where the value of respect and protection for elders and seniors is learned.

Without these practices, risks arise for the new generation in the loss of values and cultural identity. And it is when price increases jeopardise access to food for the family that household heads have to find viable alternatives. So when one informant says: 'we use the gas stove and go to bed early so as not to suffer the cold', we understand it is a viable solution, but it is not an ideal one. The family no longer meets, their relationships are no longer promoted through talk and ancestral knowledge is no longer being transmitted. This is particularly important when we remember that the values that are exchanged around the warm fire in the family kitchen, are the first school for the younger generation.

\section{The positives and negatives}

Among our household interviewees and key informants, there are a range of opinions about the positives and negatives of the shift away from firewood. Many spoke of the negative effect on family cohesion and children's learning about cultural heritage. They felt that the loss of the harmonious and educational space around the fire was putting family and tradition at risk. However, they also pointed to a number of positives in relation to the shift. For example, with less cooking there is less pressure on unpaid care work. Several respondents, both male and female, pointed to the fact that the use of gas instead of firewood is not only cheaper, but it also makes food preparation a lot easier and more convenient: 'Cooking with firewood involves much work such as: collecting/ buying firewood, put it together to burn and to be alert to keep the fire burning and not fading. And all this work is done by women. ${ }^{13}$ 'With a gas stove it is more practical', said Ms M. in 2014, 21 -year-old community leader, from Chichicastenango, 'only 
light the gas and wait until everything is cooked.' On the other hand, some respondents also argued that 'People have become lazy and want things faster; especially young people and above all young women' ${ }^{14}$ Others point to the negative effects on the natural environment of the indiscriminate and irresponsible use of firewood, so they see the shift to propane gas for the preparation of their food as a positive change. ${ }^{15}$

\section{Conclusion}

When it comes to basic necessities such as food and fuel, the low-income population is severely affected by rising and volatile prices, since people on low and precarious incomes (and especially those in rural areas) do not produce enough income to satisfy all of their needs, even when food prices are low. Food and fuel price rises can violate food security in the first instance by compromising the diet for the average urban and rural family and, in the second instance, it can also have cultural effects. Time-saving for women is important, but it is often at the cost of cultural patterns of eating together and parenting. Of course, there has always been resistance from people and communities, mostly indigenous, to ensure that customs both in the home and in the community remain strong and do not disappear.

Despite being aware of these factors, the state has not implemented measures to reduce the impact of food price volatility on the most vulnerable in the Guatemalan population. Several governments in Guatemala have been applauded for proposals and public policies that, in their design, present viable solutions to solve the effects arising from the volatility of food prices. Unfortunately, these

\section{Notes}

1 A tamalito, little tamal or little tameles is corn dough with a meat and spice filling wrapped in leaves and steamed.

2 Household key informants in the Chugüexá Primero community and Chichicastenango, Life in a Time of Food Price Volatility Research, Year 3, 2014.

3 A tarea is a load of firewood, $3.35 \mathrm{~m}$ long, $84 \mathrm{~cm}$ high and $40 \mathrm{~cm}$ wide. It is estimated that a household with five members uses 1 tarea of firewood per month. However, Guatemalan rural families are larger and are usually integrated into extended families.

4 Ms G., 21 years old, housewife, Chichicastenango, 2014.

5 For the first quarter of 2015, a decrease in the price of propane was seen down to the average of GTQ94.67 (US\$12.27) (MEM 2015). proposals have remained on paper only and although resources have been allocated for their implementation, they seem not to reach the people. Culture has been delegated as the responsibility of the formal education sector. Hunger has become the responsibility of the social protection sector. Current solutions are not tackling the structural and societal elements of the problem. The problem of the volatility of food prices, its effects and solutions must be studied holistically. As we have demonstrated in the Life in a Time of Food Price Volatility study, it is important to identify all the implications of this phenomenon to establish solutions that are broad enough to respond to all its consequences. Not least in importance are cultural patterns and the wealth that they represent for a country. These are not merely about tourism and commerce, but have value in the lives of each of the inhabitants of a country. The identity of a country depends on the identity of each of its inhabitants and it is around the fire that education begins.

People gather to eat, drink, talk and celebrate.

There is no celebration without food. As in the past, around the fire, traditions are cooked. Through food, people turn to their childhood and recreate unforgettable moments, which they share with the family, creating everyday history, sharing feelings and consolidating family and friendships. Business is done while eating, love affairs are strengthened with a family meal; the entire course of human life is crossed in its everyday life around the food and the cooking fire. But it is evident that its form is changing. There are many reasons for this, but one of them, evident in this study, is that prices are a threat that can change people's lives.

6 Interview, Chugüexá Primero, 2014.

7 In the first quarter of 2015, the price of propane fell to GTQ90.00 (US\$11.66).

8 Ms C., 21 years old, community promoter, Chugüexá Primero, 2014.

9 Miss P., 23 years old, health promoter, Chichicastenango, 2014.

10 A temazcal is a type of sweat lodge which originated with pre-Hispanic indigenous peoples in Mesoamerica. The word temazcal comes from the Nahuatl word temāzcalli ('house of heat'), or possibly from the Aztec teme (to bathe) and calli (house).

$11 \mathrm{Mr}$ M., 34 years old, teacher and community leader, Chugüexá Primero, 2014.

12 Apazote is an aromatic plant, used as a flavouring and as a medicinal plant in many Latin American countries. 
$13 \mathrm{Mr}$ V., 34 years old, teacher and community leader, Chugüexá Primero, 2014.

14 Mrs L., 56 years old, housewife, Chugüexá Primero, 2014.

\section{References}

de León, A. (2009) 'Estudio de Prefactibilidad, para la Implementación de Energía Solar, como Alternativa Energética, para la Producción de Agua Caliente Sanitaria, En Centros de Salud Tipo B, San Miguel Ixtahuacán, San Marcos', Universidad de San Carlos thesis, Guatemala

DIGEBI (Dirección General de Educación Bilingüe Intercultural) (2009) 'Mapa Lingüístico de Guatemala', [inguistic map of Guatemala], Ministerio de Educación, Guatemala, www.mineduc. gob.gt/digebi/mapaLinguistico.html (accessed 16 August 2015)

INAB (National Forestry Institute), Instituto de Agricultura, Recursos Naturales y Ambiente (IARNA) and the Food and Agriculture Organization (FAO) (2012) Oferta y Demanda de Leña en la República de Guatemala, Guatemala City: INAB

INE (National Statistical Institute) (2015a)

IPC Guatemala (Consumer Price Index of Guatemala) 2000-2015, Guatemala, www.ine.gob.gt/sistema/uploads/2015/08/07/ Me7zZrDiXUhOisErSyl tzmWW123pKS5C.pdf (accessed 6 September 2015)

INE (National Statistical Institute) (2015b) CBA Guatemala (Basic Food Basket of Guatemala) 2001-2015, Guatemala, www.ine.gob.gt/index. $\mathrm{php} /$ estadisticas/tema-indicadores (accessed 6 September 2015)

MEM (Ministerio Energía y Minas) (2015) Monitoreo del Gas Líquido del Petróleo a Agosto 2015, www.mem.gob.gt/wp-content/uploads/2012/ 05/HISTORIAL-GLP-RESUMEN-POREMPRESA-2015-6.pdf (accessed 23 August 2015) Núñez, G. (1998) Patrones de Crianza del Niño Maya Guatemalteco (Área Kaqchikel), Guatemala City:
15 Mrs R., 25 years old, housewife and single mother, Chichicastenango, 2014.

Universidad Rafael Landívar, Instituto de Lingüística

Observatorio del Gasto Social (2008) La Tenencia de la Tierra y la Conflictividad Agraria en Guatemala, Coordinadora Nacional de Cooperativas (CONGCOOP) y Centro Internacional para Investigaciones en Derechos Humanos (CIIDH), www.congcoop.org.gt/images/Estudio_de_ Tierra.pdf (accessed 1 September 2015)

Ramírez, F. (2009) 'Fuente de Energía. La Leña es la Mayor Fuente de Energía en los Hogares País, y su Precio Millonario no Está Incluido en Cuentas Nacionales las', Revista Domingo, 11 January, http://servicios.prensalibre.com/pl/domingo/ archivo/revistad/2009/enero/11/fondo.shtml (accessed 4 June 2015)

REDSAG (Red de Seguridad Alimentaria de Guatemala) (2012) Estudio Sobre la Volatilidad y el Encarecimiento de los Precios de los Alimentos en Guatemala, www.redsag.net/ files/publicaciones/Informe_Volatilidad_ Alimentos_CompletoVf_05122012.pdf (accessed 1 September 2015)

Rossi, L. (n.d.) 'Historia del Comer. Lazo Social y Tradición Cultural', Revista Electrónica de la Universidad de Psicología - UBA, http://intersecciones.psi.uba.ar/index. php?option $=$ com_content\&view $=$ article\&id $=195$ :historia-del-comer-lazo-social-y-tradicion-cultur al\&catid $=10$ :vigencia\&Itemid $=1$ (accessed 4 June 2015)

Zavala, M. (2014) 'Ambientalistas Advierten por Deforestación y Suelos', Siglo 21, 27 January, http://m.s21.com.gt/nacionales/2014/01/27/ ambientalistas-advierten-deforestacion-suelos (accessed 4 May 2015) 